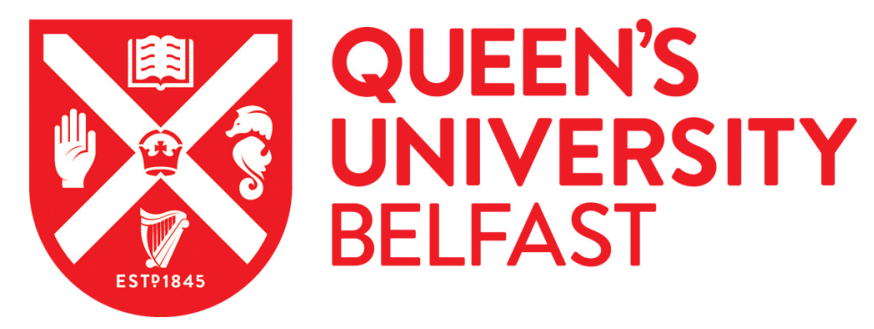

\title{
The Processes of New Product Development Recentralization Towards a Transnational Emphasis in Multinational Corporations
}

Liu, Y. (2019). The Processes of New Product Development Recentralization Towards a Transnational Emphasis in Multinational Corporations. Journal of International Management, 25(1), 19-36. https://doi.org/10.1016/j.intman.2018.05.003

Published in:

Journal of International Management

Document Version:

Peer reviewed version

Queen's University Belfast - Research Portal:

Link to publication record in Queen's University Belfast Research Portal

Publisher rights

Copyright 2018 Elsevier.

This manuscript is distributed under a Creative Commons Attribution-NonCommercial-NoDerivs License

(https://creativecommons.org/licenses/by-nc-nd/4.0/), which permits distribution and reproduction for non-commercial purposes, provided the author and source are cited.

\section{General rights}

Copyright for the publications made accessible via the Queen's University Belfast Research Portal is retained by the author(s) and / or other copyright owners and it is a condition of accessing these publications that users recognise and abide by the legal requirements associated with these rights.

Take down policy

The Research Portal is Queen's institutional repository that provides access to Queen's research output. Every effort has been made to ensure that content in the Research Portal does not infringe any person's rights, or applicable UK laws. If you discover content in the Research Portal that you believe breaches copyright or violates any law, please contact openaccess@qub.ac.uk. 
The processes of new product development recentralization towards a transnational emphasis in multinational corporations

\author{
Yang Liu * \\ Queen's Management School \\ Queen's University Belfast \\ Riddel Hall, 185 Stranmillis Road \\ Belfast, BT9 5EE, UK \\ yang_liu2011@yahoo.com \\ +447551753632
}

* Corresponding author. 


\title{
The processes of new product development recentralization towards a transnational emphasis in multinational corporations
}

\begin{abstract}
Studies on R\&D internationalization have identified the decentralization-recentralization pattern of many multinational corporations (MNCs). Studies have also indicated that MNCs tend to pursue a transnational emphasis during $R \& D$ recentralization. This research focuses on recentralization of new product development (NPD) in MNCs and aims to reveal different processes of it towards a transnational emphasis. Through a qualitative case study of four MNCs, the NPD recentralization process was explored in two important dimensions - power centralization and pluralistic input. Four process variants were discovered, showing different approaches to power centralization and pluralistic input. The processes of recentralization are novel to the area of R\&D internationalization. This study also advances our understanding of R\&D recentralization with a focus on NPD fulfilling market demand, which has not been well addressed in prior studies. In addition, this study generates insights for transnational management.
\end{abstract}

Keywords: R\&D internationalization; recentralization; new product development; multinational corporations; transnational management. 


\section{Introduction}

$\mathrm{R} \& \mathrm{D}$ internationalization has received considerable attention over the past decades (Asakawa and Som, 2008; Awate et al., 2015; Hsu et al., 2015; Patel and Vega, 1999; Von Zedtwitz et al., 2004; Wortmann, 1990). With internationalized R\&D (owning overseas R\&D centers), multinational corporations (MNCs) can gain competitive advantage through accessing local knowledge and leveraging locational innovation advantage (Un and Rodríguez, 2018; von Zedtwitz and Gassmann, 2002).

Research has revealed the decentralization-recentralization pattern (or embeddedness before integration) of R\&D internationalization of many MNCs (Chen et al., 2012; Christensen, 2002; Gassmann and von Zedwitz, 1999; Granstrand, 1999; Håkanson, 1990; Niosi, 1999). For companies adopting this path, they tend to adopt a decentralized R\&D structure at an early stage of R\&D internationalization. Local R\&D units are granted local autonomy to achieve local embeddedness which helps to access local technological and market knowledge and cultivate new knowledge (Lehrer and Asakawa, 2003). However, with the increasing number of autonomous R\&D units, coordination becomes more difficult and duplication of efforts is more likely to happen (Gassmann and von Zedwitz, 1999; Granstrand et al., 1993). With “growing coordination problems” (Chen et al., 2012, p. 1545), MNCs will then recentralize R\&D for better control and coordination. Such recentralization is necessary for MNCs to efficiently leverage knowledge at the global scale and avoid duplication. While recentralization can lead to a higher innovation performance in the long run, it has great challenges as well, such as the conversion loss (Chen et al., 2012). The conversion loss is caused by the autonomy-control tension and the disruptive effect on projects during the 
recentralization process. However, we still have very limited knowledge of the processes of $R \& D$ recentralization - how $R \& D$ recentralization can be done in MNCs. It is also unclear whether there are different processes.

In addition, prior studies on $R \& D$ recentralization have mainly focused on the research function of R\&D, and the development function or the new product development (NPD) task has not been sufficiently investigated. These studies focused on technological opportunities overseas and used the patent data to measure innovation (Belderbos et al., 2013; Chen et al., 2012; Guellec and de la Potterie, 2001). The development function, applying patented knowledge or technologies to serve the markets, more directly affects firms’ financial performance (Burgelman et al., 1996; Shu et al., 2015; Wheelwright and Clark, 1992). Yet we have limited insights on how NPD can be recentralized. In NPD, market requirements need to be considered throughout the NPD projects in order to develop products appealing to customers (Griffin and Hauser, 1993), which can complicate the recentralization process. The literature indicates that two important dimensions are evident in NPD recentralization: power centralization and pluralistic (market) input. However, we still have insufficient knowledge of the specific practices and processes in the two dimensions (e.g. how to centralize power and its influence on NPD projects).

During R\&D recentralization, although control and coordination are facilitated globally, MNCs still cater to local market requirements (Chen et al., 2012). Therefore, it denotes a transition towards a transnational emphasis embracing both global integration and local responsiveness (Bartlett and Ghoshal, 1998). Power centralization and pluralistic (market) input reflect global integration and local responsiveness respectively. Prior studies suggest 
that, to realize the transnational strategy, a firm should establish an interdependent network system of specialized organizational units in different countries (Bartlett and Ghoshal, 2000; Harzing, 2000). While this can shed some light on NPD recentralization, there are still remaining issues. We still have limited knowledge regarding how to build and maintain the interdependence between country (organizational) units. For example, are there different types of interdependencies and what are their relationships?

Also, prior studies on transnational management have not focused on knowledgeintensive tasks such as NPD. For such tasks, the output relies on team members’ complex knowledge and their knowledge exchange (Cross and Cummings, 2004; Von Nordenflycht, 2010). These tasks are usually managed as projects lasting for several years (Subramaniam and Venkatraman, 2001). NPD recentralization has a potentially disruptive effect on people and projects. Transnational management studies have not fully addressed the issue of how to manage the potentially disruptive effect when MNCs are recentralizing for knowledgeintensive tasks such as NPD.

To address the above-mentioned gaps, the research question is set as: How can MNCs conduct NPD recentralization towards a transnational emphasis (from a multi-domestic emphasis)? More specifically, I aim to explore different processes of NPD recentralization, focusing on two dimensions - power centralization and pluralistic input. I also aim to analyze how interdependence between country units can be created and maintained. A qualitative case study of four MNCs was conducted to answer the research question. I found four process variants adopted by MNCs for NPD recentralization (with different practices in the two dimensions). These processes contributed to the interdependence between country units. 
This study contributes to the literature in several ways. First, I reveal the processes of NPD recentralization in MNCs, and show variation of processes across MNCs. The varied processes have not been reported in $\mathrm{R} \& \mathrm{D}$ recentralization literature. Implications are drawn for the conversion loss and the disruptive effect. Second, I show that NPD recentralization is achieved in two dimensions reflecting a transnational emphasis. This study advances our understanding regarding how the market input aspect and the cross-functional nature of NPD add to the complexity of recentralization. Finally, I generate insights for the transnational emphasis (featured as an interdependent network system). This study discovers dual interdependencies and shows how the two types of interdependencies can reinforce each other with NPD recentralization.

\section{Theoretical background}

\section{1. $R \& D$ internationalization and recentralization}

$\mathrm{R} \& \mathrm{D}$ internationalization is a process of creating or acquiring overseas $\mathrm{R} \& \mathrm{D}$ centers and managing dispersed $R \& D$ centers. Compared with domestic $R \& D$, internationalized $R \& D$ provides considerable benefits for firms such as leveraging locational innovation advantages and being close to foreign local markets (von Zedtwitz and Gassmann, 2002). Through accessing national innovation systems, firms’ R\&D gain technological knowledge in different countries and produce better innovation (Awate et al., 2015; Lehrer and Asakawa, 2003). Through being close to local markets, the firm’s R\&D gain more market knowledge and serve local markets in a better way (Gassmann and von Zedwitz, 1999; Un and Rodríguez, 2018).

Studies of R\&D internationalization have identified the decentralization-recentralization 
pattern shown by many MNCs (Chen et al., 2012; Christensen, 2002; Gassmann and von Zedwitz, 1999; Granstrand, 1999; Håkanson, 1990; Niosi, 1999). At the early stage of R\&D internationalization, firms tend to have decentralized R\&D. Local R\&D centers are granted local autonomy for better local embeddedness (Lehrer and Asakawa, 2003). Such local embeddedness contributes to the better acquisition of local knowledge and better service for local customers (Achcaoucaou et al., 2014; Asakawa, 2001; Gassmann and von Zedwitz, 1999). It also helps to gain legitimacy as local players (Lehrer and Asakawa, 2003).

Different R\&D centers having decision-making power can be coordinated by a central management team. However, with the number of overseas R\&D centers increasing, it becomes more and more difficult to coordinate these $R \& D$ centers, resulting in more duplication and insufficient leverage of knowledge at the global level (Beugelsdijk and Jindra, 2018; Granstrand et al., 1993; Leiponen and Helfat, 2011; Reger, 2004). Local embeddedness also contributes to the coordination difficulty (Beugelsdijk et al., 2017). In order to solve these problems, firms would recentralize $R \& D$ centers (as a formal means of coordination) in terms of power and control for better global coordination and integration, but local connections and sensitivity are likely to be maintained for competitiveness (Chen et al., 2012; Lehrer and Asakawa, 2003). Despite abundant studies on R\&D recentralization, we still have limited knowledge of the processes of $R \& D$ recentralization - how $R \& D$ recentralization can be conducted in MNCs and what the relevant practices are. It is also unclear whether different MNCs have different processes, which needs investigation.

Prior studies have either directly tested the positive effect of $R \& D$ recentralization on innovation performance (Chen et al., 2012) or indicated such an effect (Argyres and 
Silverman, 2004; Subramaniam and Venkatraman, 2001) in the long run. While the long-term effect of R\&D recentralization is positive, there are a lot of challenges during the process of $R \& D$ recentralization. One important challenge is the conversion loss due to the autonomy-control tension and the disruptive effect on projects during the transition (Chen et al., 2012). The tension may arise because local R\&D units want to maintain some degree of local autonomy, while the R\&D headquarters (or the lead R\&D center) want to exert some control (Asakawa, 1996). The resistance to integration/recentralization will need to be addressed by MNCs. Studies need to be done to examine how the challenges are overcome in the processes of $\mathrm{R} \& \mathrm{D}$ recentralization.

\section{2. $N P D$ recentralization dimensions}

R\&D has two different functions as indicated by the term itself - research and development. The research function produces scientific achievements and patented technological inventions; the development function conducts new product development applying new technologies and knowledge into products to serve the market (Moenaert and Souder, 1990; von Zedtwitz and Gassmann, 2002). Though the research function can bring patents of valuable technological inventions, Shu et al. (2015) pointed out that patenting does not equal to innovation, as firms filling more patents may not be good product innovators. Without proper NPD practices, the patented knowledge is unlikely to generate profits for firms (Burgelman et al., 1996; Chandy et al., 2006; Wheelwright and Clark, 1992).

Despite the importance of both functions in $R \& D$, prior studies on $R \& D$ internationalization and recentralization have paid more attention to the research function. This is shown in two aspects. Firstly, much analysis was done for R\&D’s scientific 
achievement and its relationship with local research communities (Asakawa, 2001; Belderbos et al., 2013; Van Beers et al., 2008). There has not been sufficient discussion on how R\&D satisfies local market requirements through new products. Secondly, mainly patent data was used to measure key variables of R\&D. For example, Chen et al. (2012) used patent citations to measure innovation performance, and adopted an entropy-type measure of patents to indicate R\&D internationalization stages. Belderbos et al. (2013) used patent applications to measure R\&D activities in a country. Guellec and de la Potterie (2001) presented three patent-based indicators to measure international R\&D collaboration taking into account cross-border ownership of inventions.

More studies are needed to understand NPD recentralization due to limited insights on it. In order to develop appealing products and achieve a high performance, local market requirements need to be taken into account throughout the NPD process (Wheelwright and Clark, 1992). Market requirements and product design features are linked through certain tools (Griffin and Hauser, 1993). The way to handling market requirements is likely to affect NPD recentralization, as it needs to be managed at the global scale in MNCs.

The literature offers some clues on how to achieve NPD recentralization. Research indicates that strengthening power and control by $R \& D$ headquarters (or the lead R\&D center) is the key to facilitating more effective global coordination and integration (Argyres and Silverman, 2004; Cheng and Bolon, 1993; Meyer and Mizushima, 1989; Nobel and Birkinshaw, 1998). The result is that one lead $R \& D$ center is in charge of defining tasks and roles of each R\&D center in projects and monitoring project activities (Cheng and Bolon, 1993; Chiesa, 2000). To make sure that the developed products are suitable for different 
national markets, the lead $R \& D$ center should seek the intensive input of market requirements from local markets, which forms pluralistic (market) input (Kleinschmidt et al., 2007; Subramaniam et al., 1998; Subramaniam and Venkatraman, 2001). The development and application of information and communication technology (ICT) have made cross-border communication more convenient (Jarvenpaa and Leidner, 1999; McDonough III et al., 2001), thus making the pluralistic input in NPD easier. While previous studies have indicated that both power centralization and pluralistic input are needed in NPD recentralization, it is still unclear regarding the different practices and processes for each. Power centralization and pluralistic input (their approaches and relevant processes) can be considered as the two dimensions of NPD recentralization, and more studies are needed to understand how NPD recentralization can be achieved along the two dimensions. For example, what are the specific approaches to pluralistic input? Under what circumstances will a certain approach be adopted? There is likely variation of NPD recentralization across MNCs, which this study aims to reveal.

\subsection{The transnational emphasis}

There are different strategies for MNCs to manage overseas subsidiaries. Bartlett and Ghoshal (2000) proposed four strategies: multi-domestic, international, global, and transnational. The multi-domestic strategy emphasizes local responsiveness. The global strategy stresses global integration and efficiency. The international strategy tends to exploit home-country competencies abroad with compromises of global integration and local responsiveness. The transnational strategy, however, emphasizes both high global integration and high local responsiveness and it overcomes the trade-off between the two. While different 
MNCs adopt different strategies, studies have highlighted the advantages of the transnational strategy - it outperforms other strategic postures due to internal efficiency, flexibility, and local sensitivity (Kim et al., 2005; Luo, 1999). Such advantages are more significant when the level of internationalization is high for an MNC (Garbe and Richter, 2009).

Based on the analysis in Section 2.1 and 2.2, NPD recentralization denotes a transition from a multi-domestic (decentralized) emphasis to a transnational emphasis for NPD. To recentralize NPD, MNCs need to realize both power centralization and pluralistic (market) input as a sophisticated way to global NPD (Chiesa, 2000; Subramaniam et al., 1998). Power centralization (for NPD projects) is an effective approach to coordinating and integrating R\&D centers that are locally embedded (Chen et al., 2012). Pluralistic input helps MNCs to be responsive to local market requirements (Subramaniam and Venkatraman, 2001).

The transnational management studies have offered some insights regarding how to realize the transnational strategy. One important approach is that an MNC establishes an interdependent network system of specialized organizational units in different countries (Bartlett and Ghoshal, 2000). These organizational units can possess different competencies and they depend on each other to achieve organizational objectives. This approach is supported by the R\&D recentralization research as well (Chen et al., 2012). However, we have limited knowledge regarding how to establish and maintain the interdependence. Prior scholars have pointed out several approaches, such as redesigning responsibilities of organizational units, changing the relationships between them, altering the reward system for them, and building the trust between them (Bartlett and Ghoshal, 1988, 1998; Perlmutter, 1969), but it is still unclear what are different types of interdependencies and their relations. 
Specifically for NPD recentralization, both technologies and market needs are playing a role. How subsidiaries depend on each other in these aspects is to be examined. Also, given the challenges of maintaining the interdependence such as potential competition between subsidiaries for limited resources in MNCs (Luo, 2005), some reinforcing mechanisms are likely to be in place, which needs to be investigated.

Another unresolved issue of the transnational management research is an insufficient focus on knowledge-intensive tasks and potential disruptions in transitions. For knowledgeintensive tasks, the output relies on team members' complex knowledge (Cross and Cummings, 2004) and their knowledge exchange (Von Nordenflycht, 2010). NPD is a knowledge-intensive task manifested by the cross-functional nature, the frequent communication between team members and the risk of failure (Castellion and Markham, 2013; Wheelwright and Clark, 1992). NPD is also a project-based task with each project lasting for several years (Subramaniam and Venkatraman, 2001; Wheelwright and Clark, 1992). For each project, there are certain project objectives that direct project activities (Ulrich and Eppinger, 2012). Organizational transitions may affect the project objectives and team members (in terms of composition and roles) possessing key knowledge (Amburgey et al., 1993). Therefore, conducting NPD recentralization towards a transnational emphasis can have a potentially disruptive effect on team members and projects, which may contribute to the conversion loss (Chen et al., 2012). This study, through exploring NPD recentralization, can also advance our understanding regarding how to manage the disruptive effect and what can affect the level of disruption.

\section{Methods}


This study adopts a qualitative multiple-case study approach. The qualitative approach is suitable for an explorative study and answering a "how" question (Yin, 2009). As there are very limited studies on how MNCs conduct NPD recentralization towards a transnational emphasis, a qualitative study is likely to generate insights through understanding the complex phenomenon. Through a multiple-case design, replication is achieved so that findings apply to different contexts (Eisenhardt and Graebner, 2007; Yin, 2009).

\subsection{Case sampling}

Theoretical sampling is adopted to choose case companies that are suitable for answering the research question (Eisenhardt, 1989; Eisenhardt and Graebner, 2007). The criteria for choosing the case firms/MNCs are as following: The firms are MNCs which have substantial business overseas; The MNCs are in certain industries where R\&D intensities are relatively high (e.g. the automotive industry); The MNCs previously had a decentralized (multi-domestic) organizational structure of NPD; The MNCs have undergone NPD recentralization towards a transnational emphasis (i.e. emphasizing both global integration and local responsiveness); Successful outcome - MNCs have completed NPD recentralization as expected (i.e. no shifting back) and showed better performances (i.e. more profit) after NPD recentralization.

With the above criteria, in 2012 I used the Forbes Global $2000^{1}$ list as the basis for case selection. Through analyzing the available secondary data (e.g. news articles and annual reports) and discussing with four senior business consultants (who have extensive consulting experience in different industries), I identified 18 MNCs that can meet the criteria. Eventually,

\footnotetext{
${ }^{1}$ This list was chosen because many firms in the list had high levels of internationalization. There are, however, many firms not suitable for this study, such as firms having no R\&D function or low R\&D intensity.
} 
I chose and accessed four MNCs (Car Corp, Switch Corp, Cleaning Corp, and Fridge Corp) which are the case firms for this study. Table 1 shows the summary of four MNCs.

Insert Table 1 about here

I chose these four specific MNCs out of the 18. The basis of my choice is that I intentionally chose ones that are diverse in some aspects so as to have broadened views and extend emergent theory (Eisenhardt, 1989; Lawrence and Dover, 2015). My aim was to discover different processes of NPD recentralization. Therefore, I chose MNCs that vary in conditions before NPD recentralization and NPD process characteristics. The four cases are sufficiently diverse - diverse enough to generate interesting insights through comparisons but not too diverse (i.e. not making findings overly complicated). Eisenhardt (1989) indicated that four cases can work well in terms of generating complex and convincing theories.

These four MNCs are also different in revenues and times of starting NPD recentralization, but based on senior business consultants’ opinion and my own observation, revenues did not affect the process of NPD recentralization in the four MNCs. Although the times are different, it is the key events (e.g. economic crisis) that matter, rather than the time itself. The industrial contexts of automotive, power products, cleaning products, and home appliance industries are different, but they all have heterogeneous market requirements across countries to attend to.

\subsection{Research setting}

The four MNCs all have experienced the decentralization-recentralization pattern of R\&D. Originally Car Corp only had an R\&D center in the home country (the U.S.) designing 
cars for sale in the global market. Then starting from 1930s Car Corp internationalized R\&D mainly through the greenfield mode. It established R\&D centers in Germany, the U.K., Brazil, and Australia. The R\&D structure was decentralized with high local autonomy in $R \& D$ centers. This helped each R\&D center to better embed locally and respond to local market requirements. However, it also caused low efficiency resulting in high costs and compromised product quality. Suffering from a poor financial performance due to more intense industrial competition, Car Corp recentralized NPD in 2007, assigning the German R\&D center as the lead center for small and medium cars due to its expertise in these areas. After NPD recentralization, all R\&D centers were well coordinated globally. Duplication was mitigated as all cars in different countries are based on the global car platforms. Resources were leveraged at the global scale, enhancing product quality and profitability.

For Switch Corp, R\&D internationalization started in the 1970s, mainly through acquisitions. It had adopted a decentralized structure of $R \& D$ since the beginning of $R \& D$ internationalization. The acquired companies with $R \& D$ units maintained autonomous operations to better serve local markets and collaborate with local organizations. These R\&D centers were located in 15 countries in different continents. Due to poor coordination and efficiency, the firm observed a declining profit at the end of the 1990s. In 2001, it conducted NPD recentralization. Lead R\&D centers were assigned for product categories. Profitability was enhanced as a result of global coordination of R\&D centers.

For Cleaning Corp, it started R\&D internationalization in the 1970s through continuous acquisitions in Europe, Asia, and South America. The R\&D structure was decentralized for these $R \& D$ centers to better tap the local knowledge and serve local markets. Spotting the 
opportunity of improving the R\&D operations, in 1998 the firms started NPD recentralization lasting for over a decade. NPD was first centralized to regional lead centers and then global lead centers. Products were more innovative with lower costs.

Fridge Corp started R\&D internationalization in the 1960s through continuous acquisitions, many of which happened in European countries. These acquired R\&D units maintained independent operations, so the R\&D was highly decentralized. In 1992, to achieve better coordination, Fridge Corp started to recentralize its NPD in Europe to a regional lead R\&D center. NPD recentralization contributed to Fridge Corp’s better product innovation and lower engineering costs.

\subsection{Data collection}

Data were collected mainly through interviews, supplemented by secondary sources (i.e. internal documents, company websites, news articles, and annual reports). Most interviews were conducted between 2013 and 2015. In 2017, I conducted several more interviews for additional questions emerged from data analysis (such as interdependence between organizational units in more recent times). In total, 57 interviews were conducted in the four MNCs. The interviews lasted for about 1 hour 20 minutes on average. Informants are in different positions (see Table 1). All interviews were recorded and transcribed for analysis. The questions of the interviews include: What was the organizational structure of R\&D/NPD in history? How did the structure change over the years? Why was it changing that way? Was there a disruptive effect in transition? What were/are the roles of (relationships between) different $R \& D$ centers (and local marketing)? How to cater to market requirements from different countries in NPD? What are the roles of ICT tools? How were NPD activities 
conducted in the old and new structure of $\mathrm{R} \& \mathrm{D}$ ? The data of company websites, news articles, and annual reports mainly helped me to understand the contexts of the companies.

In the four MNCs, NPD recentralization happened at least several years before the interviews in 2013-2015. However, in supporting my research, the interviewees retrieved some internal documents made at different times (e.g. organizational charts, NPD process documents, NPD projects documents, and PowerPoint slides for meetings). These documents were used during the interviews to help informants recall what happened more precisely. To further mitigate the bias of informants, I cross-checked answers with different informants to reach data triangulation (Yin, 2009).

\subsection{Data analysis}

Data were analyzed through a highly iterative process. I first described the events or facts happened in each case company over the time period of NPD recentralization. Next, I narrowed my focus on the events or facts related to two dimensions of NPD recentralization (power centralization and pluralistic input). Then I conducted coding for the events or facts. For example, relevant events or facts were first coded into first-order categories of 'Designating lead centers and support centers' and 'Rapid change of the reporting structure'. Then these two were coded into a second-order theme, 'Reporting structure-driven centralization'. Then this second-order theme was further coded into an aggregate dimension, ‘Approach to power centralization'. In the coding process, I first conducted within-case analysis and then conducted cross-case analysis. In this stage, I found that MNCs adopted different approaches to power centralization and pluralistic input, but each MNC primarily relied on one approach for each dimension. 
After the themes were generated, I went further to analyze the relationships between the themes. I also aimed to explain different approaches to power centralization and pluralistic input. Through discovering the relationships between the themes, I established the processes of NPD recentralization. In total, there are four process variants due to different approaches to power centralization and pluralistic input. These four process variants are the main findings of this study. To refine my findings, I went back and forth between data, findings, and literature (Eisenhardt, 1989). To mitigate the bias, I sent research findings back to companies and sought feedback (Hite, 2005; Miles and Huberman, 1994). The informants confirmed the analysis results.

\section{NPD recentralization in four case MNCs}

In this section, each case is presented regarding how NPD recentralization was conducted in two dimensions. Table 2 shows some quotes from the interviewees. The cross-case analysis results are presented in Section 5.

\section{Insert Table 2 about here}

\subsection{Car Corp}

\subsubsection{The power centralization dimension}

For Car Corp, it historically developed cars independently in regions of Europe, North America, and Asia Pacific. Local R\&D units had the authority to initiate NPD projects without reporting to each other.

In 2007, Car Corp had made huge amounts of losses for two consecutive years (since 2005). Much of the loss can be attributed to competition with Japanese automakers which had 
more centralized R\&D structures. Japanese automakers offered products with better value for money through avoiding duplication and concentrating engineering resources. European automakers offered high quality through a similar method. In comparison, Car Corp’s cars had relatively lower quality/price ratios due to decentralized engineering resources. The situation was worsened by the financial crisis, so Car Corp was in an urgent situation.

NPD recentralization started in 2007 and completed in late 2008. During the time, the high-level management designed a new reporting structure through redefining the relationships between $R \& D$ centers (i.e. the lead center and support centers for a product category) and the specific role for each $R \& D$ center. Then the new structure was implemented. For small and medium cars, the German R\&D center became the global lead center. It initiated NPD projects, set up the project team, and worked on the global platform of cars (e.g. car body and chassis). Other centers became support centers and completed assigned tasks. For example, the Asia-Pacific center was “assigned to deal with the unique engineering requirements for their local market” under the supervision of the German center, according to an R\&D manager. The American center developed some local features and large engines for the global market due to its expertise. These were all specified and enforced by headquarters rapidly. This was actually part of the efforts to enhance integration for the whole company.

Organizational members experienced a significant disruptive effect on project operations due to the radical change of the reporting structure. Under the new (global) reporting structure, the lead center had greater responsibility. Therefore, the ongoing (regional) projects were suddenly changed to global projects with different objectives. As a result, Car Corp conducted project rework after altering the reporting structure. It means that the team 
members did not continue to finish the project tasks as planned previously, but they went back to an early stage of the NPD process to modify the products for the global market. For example, Car Corp’s B-car NPD project was in the product testing stage during the change. Before the change, the car was being designed for the European market only. However, after the reporting structure was changed, the German lead center became responsible for developing cars for the global market. This caused project rework for the B-car to meet the new project objectives. Initially, only the hatchback version of the car was being developed. Because of North Americans' requirement of the sedan version, the project team went back to the conceptual design stage and added the sedan version into the project. The front part of the car body was modified to suit the sedan version, but the team aimed to minimize the modification even though they returned to an early stage of the NPD process. The car body of the sedan version was not deemed as ideal due to the late modification.

Power centralization led to the interdependence between R\&D centers in NPD projects. Despite the expertise of small and medium cars in the German (lead) center, it had to "deal with the different regulatory requirements for each of the markets” and develop “more powertrain options and emissions calibrations” for the global market, according to an R\&D manager. Only through collaboration can high-quality products be developed.

\subsubsection{The pluralistic input dimension}

For Car Corp, originally each region collected and considered only regional requirements for each product. Before NPD recentralization, Car Corp had a very clearly defined NPD process detailing objectives and tasks of each stage, including when marketing personnel should provide input to $R \& D$. This process was strictly implemented in all $R \& D$ 
centers (with some modifications), although they were independent in developing new products. In all R\&D centers, managers and engineers strictly followed the process. This helped to organize a big project team comprised of hundreds of engineers for car development, while it could also slow down the projects.

Strict implementation of the (NPD) process means for a project, all steps must be done and all documents must be submitted for review meetings. Skipping required tasks or documents was not allowed for the NPD process. It did allow project rework, but the team must then go back to an early phase of the process to perform all steps and activities again ${ }^{2}$.

Due to strict implementation of the NPD process, Car Corp adopted the process-driven approach to pluralistic input. This was because organizational members were accustomed to following the process. During R\&D recentralization, the NPD process was altered to incorporate pluralistic input from different regions. The new process demanded that in an NPD project, the marketing department at each region submit market requirements to the lead R\&D center and update such information over time. This was done through the online process management system/software. Also, at certain defined points during an NPD project, the lead R\&D center must seek feedback from marketing departments or customers in all regions for the designs/prototypes.

Interdependence was formed between the lead R\&D center and regional marketing departments. The product director was mainly to oversee the implementation of the process. $\mathrm{He} /$ she did not handle the specific market requirements (which is different from Switch Corp and Fridge Corp).

\footnotetext{
2 I thank an anonymous reviewer for pointing out this issue.
} 
As a result of the new NPD process, Car Corp had bigger review meetings in NPD. In the review meetings, marketing personnel from all regions (North America, South America, Europe, and Asia Pacific) were present. They provided different feedback due to different requirements (e.g. level of masculinity for car design) and discussed how the car design should be modified. Tensions often existed in these meetings, but these review meetings helped the lead R\&D center to meet local market requirements.

\subsubsection{Summary}

With decentralized R\&D and adverse financial conditions, Car Corp reacted through conducting reporting structure-driven centralization which then caused (NPD) projects disruption and rework. As Car Corp had flexible implementation of the (NPD) process initially, it conducted process-driven input leading to bigger review meetings with some tensions. Overall, NPD recentralization in Car Corp shows radical change of the organization (in the reporting structure and the NPD process) which happened relatively rapidly.

\subsection{Switch Corp}

\subsubsection{The power centralization dimension}

Before NPD recentralization, Switch Corp’s R\&D centers were located at factories in different countries and had the power to develop their own products without the global oversight.

In 2000, Switch Corp found that its profit had decreased by $40 \%$ over the last three years. It was mainly due to too many product variants developed by decentralized R\&D centers with duplication. The core parts of circuit breakers and switchgear could have been shared globally. High-level managers reacted to the adverse financial performance by a radical organizational 
change of R\&D.

In 2001-2002, Switch Corp’s R\&D organization was restructured, and the Product Group unit was established in headquarters. The Product Group then assigned lead centers for different product categories. For example, the Italian R\&D center was the lead center for the air-insulated switchgear (AIS) for secondary distribution systems. Other centers were support centers for this product category. The technology manager and marketing manager at the Product Group were globally responsible for initiating NPD projects, through consulting relevant lead centers. The lead center executed the NPD project and assigned tasks to support centers. The support centers needed to report the progress of tasks to the lead center regularly. The support centers could neither initiate, nor work on, their own projects. Similar to Car Corp, the reporting structure drove the change, although the capacities of R\&D centers were adjusted due to the altered responsibility. The adverse financial condition made it easier for high-level managers to persuade local R\&D centers to accept the radical change of the reporting structure.

Switch Corp had project rework for all ongoing projects after altering the reporting structure. The disruptive effect was significant. Local projects were changed to global projects under the new reporting structure. For example, the Swedish R\&D center was developing AIS secondary in a project initially for the Swedish market only. It was in the product engineering stage and all product features had been determined already. After the reporting structure was altered, the Italian center became the lead center for AIS secondary. The Swedish center passed over the ongoing project to the Italian center, which then led the project (but the Swedish center was still involved in NPD). The Italian center reconsidered 
the product features. Finally, the product design was modified in many aspects to add features needed in other countries/regions (e.g. working in high humidity and earthquake).

An R\&D manager mentioned that interdependence was formed to leverage knowledge between R\&D centers as a result of power centralization: "Main benefits are clear, that is, the sharing of the knowledge ... if you don't have some kind of knowledge, you can start to cooperate ...”

\subsubsection{The pluralistic input dimension}

For Switch Corp, prior to NPD recentralization, mainly local market requirements were considered in NPD projects. Switch Corp had a flexible implementation of the NPD process. It adopted a Stage-Gate process for NPD defining tasks for each stage and the review meeting requirements for each gate between stages. However, engineers were allowed to skip tasks in certain circumstances, and R\&D managers were allowed to skip stages when appropriate. The flexible implementation of the process made project rework easier, as engineers did not have to complete all tasks from the first phase.

Engineers and R\&D managers were accustomed to skipping tasks and relied more on only a few key informants for market requirements. Therefore, Switch Corp conducted a delegate-driven approach to pluralistic input. The position of global product manager was created as the delegate for global markets. This person was responsible for collecting demands from every country and then compiling a document with a list of product requirements globally. During NPD, the lead R\&D center kept communication with the global product manager about the requirements in the document. The global product manager ensured that the local requirements would be considered throughout the NPD. 
As a result of the delegate-driven approach, Switch Corp had frequent interaction between the global product manager and engineers. The communication started when an NPD project was initiated and lasted throughout the project. Therefore, local marketing personnel maintained their old work routines whereas the global product manager proactively communicated with local marketing. The global product manager played a critical role in assisting the lead $R \& D$ center understanding market requirements of different countries. $\mathrm{He} /$ she focused on information collection and requirements handling and thus saved some time for engineers. It is suitable for an MNC with a flexible implementation of an NPD process. The global product manager took initiatives to facilitate effective market input into NPD. He/she leveraged the flexible implementation of the NPD process to proactively maintain frequent interaction with engineers both formally and informally. The frequent interaction was helpful for understanding different market requirements and resolving trade-offs between them. It also shows interdependence between R\&D and marketing, as an R\&D manager noted: “They [customers] have quite a lot of special requirements but we try to fulfill all those.”

\subsubsection{Summary}

Initially decentralized in the R\&D structure, Switch Corp conducted reporting structure-driven centralization, reacting to the declining profit. Such centralization caused NPD projects disruption and rework. With flexible implementation of the (NPD) process, delegate-driven input was leveraged for pluralistic input. The position of global product manager in Switch Corp played a critical role in assisting the radically changed R\&D. The global product manager must adapt to the new role quickly and maintain frequent interaction 
with different parties.

\subsection{Cleaning Corp}

\subsubsection{The power centralization dimension}

At Cleaning Corp, historically the R\&D unit in each country had the capability to develop their own products. In the 1990s, Cleaning Corp actually had a positive financial performance (regarding profitability). However, through analyzing some competitors, Cleaning Corp concluded that its positive performance would not be sustainable in the long run, because its R\&D structure was not optimized. The company had good advertisement and powerful brands, but there was a duplication of R\&D efforts - some ingredients and technologies could have been shared across countries even though there were some different market requirements.

Although the situation was not urgent, Cleaning Corp changed proactively through capacity-driven centralization of NPD in an effort to have long-term competitiveness. It aimed to avoid the situation of decreasing profit through early action. Reducing capacity was conducted in two stages, regional centralization and global centralization. Starting from 1998, resources such as staff and budget were gradually shifted from local centers to regional lead centers. It was a gradual process as some people did not want to move. With fewer resources at local centers, they gradually lost the capacities to develop products and relied on regional centers for NPD. They could still modify products for local customers and give advice about local regulations, but did not have the resources to develop products from scratch. Therefore, they gradually lost power.

In 2004, global centralization happened in a similar manner in Cleaning Corp. Resources 
on new technology development were again gradually moved to the global lead center in the U.K. and regional lead centers relied on the British center for new technologies in NPD. They still developed prototypes/formulations for regional customers under the supervision of the British center. Therefore, global coordination was achieved. The reporting structure changed finally, but that was the result of altered capacities in $R \& D$ centers. With different roles, $R \& D$ centers depended on each other for NPD in terms of new technology, product prototypes, and local regulations. A scientist noted: "When we want a product, there would be some technical know-how that we could use to actually develop formulations ... we would also need to overcome the problems at the local level.” Global centralization of R\&D was conducted together with unifying brand images globally in an effort to align strategies and operations.

As a result of capacity-driven centralization, local projects were gradually replaced with regional and then global projects. Unlike project rework, project replacement had a very low disruptive effect. For example, during the regional centralization period, local NPD projects were gradually replaced with regional NPD projects over time. For ongoing (local) projects, objectives were not changed with NPD recentralization, so no rework was needed, though sometimes there was an adjustment of team members due to altered capacities. Some new (regional) projects were performed in the regional lead center with different objectives. The number of regional projects increased gradually rather than suddenly. For a long time, both local projects and regional projects existed. During global centralization, the trend was similar in that, regional projects were gradually replaced with global projects. The disruption effect was low.

\subsubsection{The pluralistic input dimension}


For Cleaning Corp, before NPD recentralization, local R\&D centers developed products only considering their local markets. An R\&D manager pointed out that they made formulations with the input of "only one [local] country requirements.” Cleaning Corp also had a strict implementation of the NPD process in all R\&D centers. The process was internally called Innovation Process Management (IPM) composed of six phases. The company used ICT systems to ease communications (e.g. documents submission) needed by the process. Product directors kept an eye on scientists and R\&D managers regarding whether they were following the process when developing products. Same was true for the marketing department. While minimizing the risk, it could also delay the projects.

During NPD recentralization, the NPD process was altered for regional/global NPD projects to have pluralistic input. The input (including washing habits and local conditions) from local marketing to regional/global lead R\&D centers was required by the process in different stages of NPD. In fact, two different NPD processes (old and new) for different types of projects were in use during the slow transition. Organizational members would, therefore, follow different processes depending on the projects.

As a consequence of the altered NPD process, project review meetings became bigger for regional/global projects. They were held at certain points of time in NPD projects. The meetings tended to be very long in order to reconcile different opinions of local marketing personnel, but these helped the products to be locally appealing.

The interdependence between local marketing and the lead R\&D center was formed to develop locally appealing products. A local marketing manager mentioned: "With the ability to get people resources, better resources, build bigger and better innovations, we can take on 
bigger challenges trying to deliver bigger benefits to consumers ... you can only do that if you are operating at the global scale.”

\subsubsection{Summary}

With the positive financial performance, Cleaning Corp proactively conducted capacity-driven centralization, which caused local (NPD) projects to be gradually replaced with regional/global projects. With strict implementation of the NPD process, Cleaning Corp had process-driven input for pluralistic input, therefore, bigger review meetings were held. The organizational change happened progressively over a long time, during which period both new and old NPD processes were followed depending on the projects.

\subsection{Fridge Corp}

\subsubsection{The power centralization dimension}

Before NPD recentralization at Fridge Corp, the R\&D center in each European country had the capability to develop products. Fridge Corp had positive financial performances (regarding profitability) in years prior to 1992. However, the firm spotted the opportunity to reduce $R \& D$ costs through changing the organizational structure. To be more competitive in the global market, it acted proactively to recentralize NPD in Europe.

In 1992, Fridge Corp started to shift the local R\&D capacities to the European lead center in Italy. Many people did not want to move, so the Italian center recruited new employees over time and some employees left the company in other centers. The process was quite slow. As a consequence, the local centers relied more and more on the lead center for NPD as they lost the capability. However, they still conducted minor modifications of products (e.g. changing handles and materials). They also conducted some product testing 
related to local manufacturing processes, which shows the interdependence between R\&D centers. The interdependence was gradually enhanced over time. Along with NPD recentralization, the firm also discontinued some local brands for better unification.

With the positive financial performance, it was difficult to persuade local R\&D centers to change the reporting structure. As a result, Fridge Corp gradually reduced the capacities of R\&D centers in Europe so as to have less resistance locally.

Projects replacement happened due to the capacity-driven approach to centralization. During the period of capacity change, there were both regional and local projects initiated. The number of local projects was gradually decreasing over the years and regional projects increasing. The disruptive effect on NPD projects was low.

\subsubsection{The pluralistic input dimension}

Initially, at Fridge Corp, each local R\&D center only considered local market requirements in NPD. Fridge Corp also had a Stage-Gate NPD process which was implemented in a flexible way in all R\&D centers. Steps and tasks may be skipped by NPD teams.

As a result, Fridge Corp conducted a delegate-driven approach to pluralistic input. The new position of European product line manager was created. He collected market requirements from all European countries through sub-region (Northern Europe, Southern Europe, Western Europe and Eastern Europe) marketing managers and then provided input to NPD projects.

For the format of input, the lead $R \& D$ center maintained frequent interaction with the European product line manager for the market requirements information. Their 
communication was at least on a weekly basis, including formal and informal means, to ensure products are suitable for different countries.

With more and more regional projects initiated to replace local projects, the role of the product line manager became more and more important. It means that, over time, he/she was involved in more (regional) projects, and the lead R\&D center had more communication with him/her for market requirements information.

A local marketing manager indicated the interdependence with the lead $R \& D$ center (through the European product line manager) for NPD: “Customers want excellent products, and that is what we need to deliver. There are local variations, but the core functions [of products] are the same, which need the best technologies globally."

\subsubsection{Summary}

Fridge Corp, with a positive financial performance, conducted capacity-driven centralization of NPD, causing local NPD projects gradually replaced with regional projects. With flexible implementation of the (NPD) process, delegate-driven input was conducted in Europe. As the organizational change happened progressively over a long time, the role of the delegate (regional product line manager) became more and more important regarding facilitating pluralistic input through interactions with different parties.

\section{NPD recentralization: A typology and a process model}

\subsection{A typology: Four process variants}

The four cases show two possibilities in each of the two dimensions (power centralization and pluralistic input) of NPD recentralization, and thus four process variants (see Figure 1). Each case offers an example of a certain process variant. Car Corp offers an 
example of process variant 1 , with reporting structure-driven centralization and process-driven input. Switch Corp offers an example of process variant 2, with reporting structure-driven centralization and delegate-driven input. Cleaning Corp offers an example of process variant 3, with capacity-driven centralization and process-driven input. Fridge Corp offers an example of process variant 4, with capacity-driven centralization and delegate-driven input. These process variants reveal the variety of approaches and processes adopted by MNCs for NPD recentralization.

Insert Figure 1 about here

\subsection{A two-dimensional process model of NPD recentralization}

Through comparing across four cases, this study reveals a two-dimensional process of NPD recentralization (see Figure 2) with four process variants. In each dimension, a specific approach is adopted depending on contingencies, and the approach has certain effects on NPD projects. Each dimension of the process is elaborated next.

Insert Figure 2 about here

\subsubsection{The power centralization dimension}

In this dimension, the four case MNCs show that the change motivation can influence the specific approach to power centralization, which then affects objectives of NPD projects (with a high or low disruptive effect on ongoing NPD projects). There are two possibilities depending on the change motivation.

One possibility (demonstrated by Car Corp and Switch Corp) is that an MNC's 
motivation to change is to react to the adverse financial performance. The MNC with the reactive change motivation tends to adopt the reporting structure-driven approach to power centralization. The reporting structure is changed swiftly. The lead R\&D center is assigned by the headquarters, and the authority for initiating and managing NPD projects is centralized to the lead R\&D center. Other R\&D centers become support centers and must report to the lead center and do the tasks assigned by the lead center ${ }^{3}$. The lead and support R\&D centers depend on each other to develop quality products for different countries. The capacity of each R\&D center may be adjusted for its new role, but the reporting structure drives the change.

The MNC with the reactive change motivation tends to adopt the reporting structure-driven approach because, with poor performances, MNCs were under the urgent situation to change $R \& D$ structure for better coordination. Altering the reporting structure is a quick (though risky) solution to low efficiency, compared with the other approach (capacity-driven centralization) which can take many years. The other reason is that, even though local R\&D centers do not want to lose power, with poor performances, it is easier for high-level management to persuade local $R \& D$ centers to accept the new structure as it is tied to the firm's survival. Under this situation, local R\&D centers can understand that the old structure no longer works.

The reporting structure-driven approach to centralization is likely to have a significant disruptive effect on ongoing (i.e. not finished) NPD projects. Project objectives are modified to suit the new structure (e.g. the global launch instead of the local launch of products) and team members are adjusted. To fulfill the new project objectives, some (rework) tasks need to

\footnotetext{
${ }^{3}$ These support R\&D centers do have some power for connecting and communicating with local R\&D/scientific communities, thus preserving local embeddedness for acquiring local knowledge.
} 
be done, such as redesigning some product components and redoing some tests. This will incur some costs, but meanwhile, the new NPD structure can bring some benefits (e.g. economies of scale and good quality).

The other possibility (as shown in Cleaning Corp and Fridge Corp) is that an MNC with a positive performance wants to maintain the global competitiveness in the long term through changing/optimizing the NPD structure. With the proactive change motivation, the MNC tends to adopt the capacity-driven approach to power centralization. The MNC gradually reduces the capacities of local $R \& D$ centers to centralize power at a lead $R \& D$ center. This takes a long time. Local R\&D centers become smaller, and the lead center becomes bigger over time. The capacity drives the change of power. With the capacities gradually reduced in local R\&D centers, they become more reliant on the lead center for NPD (for more and more projects). The lead center will take advantage of this, and have more control. At a certain point, the lead center will have the authority for initiating and managing all NPD projects, and the local centers may develop some parts or conduct product testing, under the instruction of the lead center. The interdependence between R\&D centers is created slowly.

The MNC with the proactive change motivation tends to adopt the capacity-driven approach because, in the non-urgent situation, local $R \& D$ centers will resist the change of the reporting structure as they believe they know local markets better than the lead center. It is difficult to persuade local R\&D centers to accept the new NPD structure. However, through the capacity-driven approach, local R\&D centers can hardly feel the change as it is slow.

The capacity-driven approach to centralization will have a low disruptive effect on NPD projects. The result is gradual projects replacement. During the time of change, with the 
capacities reduced, the ongoing local projects in local R\&D centers still have the same objectives. Rework is not needed, although some project team members may be changed. Some new NPD projects are affected to a larger extent. Without enough people for these new projects, local R\&D centers relied on the lead center - which initiates global projects (with global objectives) - to conduct NPD. Over time, there are fewer local projects and more global projects overall. Local projects are gradually replaced with global projects.

\subsubsection{The pluralistic input dimension}

In this dimension, the four case MNCs show that NPD process implementation can influence the specific approach to pluralistic input, and the approach can affect how the input format can be changed in NPD projects. There are two possibilities depending on the level of process implementation flexibility.

One possibility (exemplified by Car Corp and Cleaning Corp) is that an MNC has an NPD process that is strictly implemented. Organizational members (including engineers and marketing personnel) are not allowed to skip process stages/tasks and they need to do each task and submit each document specified by the NPD process. Such an MNC tends to adopt the process-driven approach to pluralistic input. The NPD process is altered to achieve pluralistic input. The new NPD process requires the NPD project team to seek input from local marketing departments for local market requirements throughout the process.

The MNC with strict implementation of the NPD process tends to adopt the process-driven approach, because people are accustomed to a very disciplined way of organizing NPD activities and they would follow the NPD process. For them, altering the NPD process is a better option for realizing pluralistic input, as local marketing personnel 
would provide input to R\&D at the right times, and R\&D would seek feedback from local marketing (as required by the process) at the right times to ensure products are suitable for the global market. The interdependence between the lead R\&D center and local marketing is formed. Compared to the delegate-driven approach (shown in Switch Corp and Fridge Corp), the advantage of the process-driven is that it can facilitate direct communication between engineers and marketing personnel that helps engineers to more precisely understand market requirements across countries.

The process-driven approach to pluralistic input will lead to bigger review meetings as the new input format in NPD projects, due to more participants at these meetings. During the review meetings, marketing personnel from all major markets (countries) are present, offering feedback to the product designs. Though with tensions, bigger review meetings are more informative. They are important for products to be suitable for the global market. Because the costs of arranging such large meetings were high, the number of meetings will be relatively low (e.g. three or four for a project).

The other possibility (shown in Switch Corp and Fridge Corp) is that an MNC has flexible implementation of an NPD process, allowing organizational members (e.g. engineers and marketing personnel) to skip tasks, documents, and even whole stages when considered as appropriate. Therefore, organizational members have more freedom regarding how to conduct NPD activities and they are accustomed to the freedom. Such an MNC tends to adopt the delegate-driven approach to pluralistic input. New positions are created to facilitate pluralistic input. They are delegates for marketing personnel in all countries. They are responsible for collecting local requirements from different countries and providing the 
information to the lead $R \& D$ center. These positions are often named as global product manager or product line manager. Usually, engineers do not communicate directly with local marketing. The interdependence between the lead R\&D center and local marketing is formed through a delegate. In Car Corp and Cleaning Corp where the process-driven approach is adopted, there were product directors, but they did not handle specific market requirements. They were mainly to ensure the NPD process was followed by organizational members.

The MNC with flexible implementation of the NPD process tends to adopt the delegate-driven approach, because with high flexibility of process implementation, even though the NPD process is changed to incorporate inputs from other countries, engineers may skip some tasks of seeking local feedback in order to complete projects quickly, as contacting local marketing and considering different requirements can be time-consuming. Also, local marketing personnel in some countries may not give input or attend review meetings, causing unrepresentative market input. Therefore, the company needs a delegate to take initiatives to ensure market requirements from all countries are well considered in NPD projects. The delegate can leverage highly flexible implementation of the NPD process to facilitate the plurality of input through formal and informal communication in NPD projects.

The delegate-driven approach will lead to frequent interaction between engineers and the delegate for global markets. This is not necessary before NPD recentralization because engineers are knowledgeable about requirements of their own countries. With the delegate-driven approach, engineers will maintain frequent communications with the delegate for market input. This is also to minimize misunderstanding of market requirements caused by indirect contact between engineers and marketing. Also, communicating with the delegate 
incurs lower costs (compared with the big meetings caused by the process-driven approach), although the delegate position itself can incur some costs. Therefore, it is easier to maintain frequent communication (formal and informal) throughout the NPD process for market input and feedback. The delegates, through frequent communication with engineers, ensure that these engineers consider and understand different market requirements across countries.

\section{Discussion}

In this study, I analyzed how NPD recentralization was conducted in each of the four case MNCs with different contexts, based on which I developed a typology and a process model of NPD recentralization towards a transnational emphasis. The process model has two dimensions - power centralization and pluralistic input. In the power centralization dimension, the change motivation affects the approach to power centralization which leads to the change of NPD project objectives. In the pluralistic input dimension, NPD process implementation influences the approach to pluralistic input which causes the input format change in NPD projects. The four MNCs used different approaches to power centralization and pluralistic input, showing four process variants.

\subsection{Theoretical implications}

\subsubsection{The processes of NPD recentralization}

Previous studies on $R \& D$ recentralization have analyzed its performance implications (Chen et al., 2012; Lehrer and Asakawa, 2003). Through focusing on the development function in R\&D recentralization, this study examines its underlying approaches and processes, therefore, adding insights on how positive performances may be achieved. Meanwhile, variation of approaches and processes is discovered showing the contingent 
nature of NPD recentralization.

Chen et al. (2012, p. 1545) argued that MNCs recentralize R\&D due to "growing coordination problems” of decentralized R\&D. However, they have not sufficiently explained how an MNC can be aware of the coordination problems or inefficiency, given that organizations can be subject to "blind spots” (Fotaki and Hyde, 2015; Geiger and Antonacopoulou, 2009). This study reveals two possibilities demonstrated by reactive and proactive motivations. For MNCs with a reactive motivation, the declining profit is a stimulus that helps them to clearly realize the coordination problems and inefficiency. For MNCs with a proactive motivation, they examine or reflect on their own organizational structures (sometimes through comparing with competitors), and detect coordination problems or inefficiency as the room for improvement.

Prior studies suggest there is conversion loss at the beginning of $R \& D$ recentralization (Asakawa, 2001; Chen et al., 2012), which is caused by the autonomy-control tension and difficulty of communication between R\&D centers embedded in different national contexts (Asakawa, 1996; Chen et al., 2012). However, this study indicates that such tension can be mitigated in two ways. The first way is to recentralize quickly when the firm is at a crisis. This is the time when the local autonomy and resistance are easier to overcome, due to more attentions to performances (Rumelt, 1995). Local R\&D centers are less resistant to giving up power as they also want the company to survive. People are also more motivated to overcome the cultural barrier to facilitate the cross-border communication under such a situation. The other way is to conduct power centralization through reducing the capacities of local R\&D centers over a long period of time. Because the change is so slow, local R\&D centers can 
hardly feel it, so they would not exert strong resistance. The level of cross-border communication increases gradually, which can facilitate mutual understanding over time.

The potentially disruptive effect is an important issue in transitions of knowledgeintensive tasks such as NPD. The disruptive effect can contribute to the conversion loss in NPD recentralization. This study shows that the disruptive effect can be high or low, depending on the power centralization approach adopted (i.e. reporting structure-driven centralization or capacity-driven centralization). However, with appropriate approaches to NPD recentralization, the negative effect of disruption can be offset by more efficient R\&D (less duplication) at least in the long run (Chen et al., 2012).

\subsubsection{Two dimensions of NPD recentralization}

Characterized as continuous consideration of market requirements and linking market requirements to product design features, NPD differentiates from the research function of R\&D (Griffin and Hauser, 1993). These characteristics also complicate the recentralization process. This study shows that the NPD recentralization process is composed of two dimensions, which are implemented simultaneously in MNCs. Consistent with prior studies, I found that NPD recentralization does not mean shifting back to the initial status of having only home-country R\&D or giving the lead R\&D center absolute authority. Rather, it means a more sophisticated way to organizing NPD in the global scale, highlighting global integration/efficiency and local responsiveness at the same time (i.e. a transnational emphasis)

(De Brentani et al., 2010; Subramaniam and Venkatraman, 2001). The power of the lead R\&D center is used reasonably to coordinate NPD activities and carefully consider market requirements from all countries. 
While some prior studies have indicated pluralistic (market) input as an important dimension of NPD recentralization or global NPD (Subramaniam and Venkatraman, 2001), this study reveals two different approaches (process-driven and delegate-driven) to pluralistic input, therefore further advancing our understanding of global NPD. This shows different levels of reliance on processes in managing NPD activities (Kleinschmidt et al., 2007). While ICT tools are widely used to assist pluralistic (market) input, the two approaches indicate that ICT tools can be used in different manners to achieve the same goal (e.g. requiring either local marketing or the global product manager to enter market requirements information).

\subsubsection{The transnational emphasis}

While transnational management studies can offer some clues on how to establish the interdependence between country (organizational) units (Bartlett and Ghoshal, 1988, 1998; Perlmutter, 1969), this study, through focusing on NPD recentralization, generates additional insights on this. Through NPD recentralization, dual interdependencies (for technological excellence and market fulfillment) between country units are established (see Figure 3), which are mutually reinforcing ${ }^{4}$. Such a reinforcing mechanism (see Figure 4, also elaborated next) contributes to the maintenance of the interdependent relationships between country units over time. Yet it has not been reported in the existing literature.

Insert Figure 3 about here

Insert Figure 4 about here

\footnotetext{
${ }^{4}$ The analysis is based on NPD activities for one product category with one lead R\&D center. An MNC can have several product categories with different lead R\&D centers, which can further complicate the interdependencies.
} 
Each country unit (subsidiary) contains an R\&D department/center and a marketing department. With the power centralization process, R\&D centers are globally coordinated. However, instead of imposing anything on local support R\&D centers, the lead R\&D center leverages the expertise of each support R\&D center (e.g. expertise in developing a component or in local regulations). This contributes to interdependence for technological excellence between the lead R\&D center and support R\&D centers. For example, between country A and country B (as shown in Figure 3), the lead R\&D center depends on the support R\&D center for components development, whereas the support center relies on the lead center for the system or interface design (so that the component can work in the system). Such interdependence and cooperation can yield products with technological excellence, which assures local marketing in country B that the globally coordinated R\&D is beneficial for the local market. Therefore, the local marketing will no longer rely on the local support R\&D center, and is more likely to trust and collaborate with the lead R\&D center, which contributes to interdependence for market fulfillment. A local marketing manager in Car Corp confirmed this with facts: "So the time is kind of right for this global development because these are all kind of global fuel-saving technologies and they need to distribute the costs.”

With the help of the pluralistic input process, local marketing (e.g. in country B) is connected with the lead R\&D center. This contributes to interdependence for market fulfillment between them. The lead R\&D center (in country A) depends on local marketing (e.g. in country B) for market requirements information (as required by headquarters), whereas local marketing relies on the lead R\&D center for locally appealing products (with local requirements incorporated). Such interdependence and cooperation can contribute to 
serving local customers. This assures the local support R\&D center (e.g. in country B) that the lead R\&D center can be trusted and this can dismiss the doubt that the lead center does not understand local market requirements as indicated by Chen et al. (2012). Therefore, the local support R\&D center will fully support the lead $R \& D$ center in operations and will no longer rely on its local marketing (in the same country). This further contributes to interdependence for technological excellence. An R\&D manager in a support R\&D center in Switch Corp said: "Now, our [local] market information [from marketing] becomes a part of global market information as input to the lead center ... they understand the global market.”

There is weak interdependence between some country units (e.g. between B and C), but this is for a specific product category. For a different product category, strong interdependence may exist between them.

\subsection{Limitations and future research}

All studies have limitations and this study is no exception. First, there are boundary conditions for this study, and future research can explore NPD recentralization beyond these boundary conditions. This study focuses on MNCs with high R\&D intensity. High R\&D intensity reflects the strategic importance of innovation and high R\&D spending (Lin et al., 2006). Such firms are more likely to pursue NPD recentralization to save R\&D costs while ensuring high product quality. However, some MNCs with low R\&D intensity may also pursue NPD recentralization to unify the brand image or positioning of the firm. They may use slightly different processes of NPD recentralization, which can be explored in the future.

Also, this study focuses on MNCs with the successful recentralization outcome. In doing so, this study reveals diverse approaches to the successful outcome, but may miss some 
factors in explaining why the MNCs are successful. Future studies can compare successful and failed MNCs, and analyze what caused the difference in the outcome. Based on findings of this study, it is expected that adopting inappropriate approaches to power centralization or pluralistic input (e.g. process-driven input under the condition of flexible implementation of the NPD process) can lead to the failure. However, other factors may play a role as well. For example, research shows that the organizational learning capability can affect NPD performance (Adams et al., 1998; Li and Yeh, 2017). Therefore, factors such as the organizational learning capability may also explain success/failure of NPD recentralization. With all these findings generated from qualitative research, a quantitative study can be conducted with a large sample to test them in a more systematical way.

In addition, findings of this study raise some interesting questions to be studied in the future. For example, in NPD recentralization, what are the roles of departments other than R\&D and marketing? Since NPD is a highly cross-functional activity (Ulrich and Eppinger, 2012), other departments (e.g. manufacturing, supply chain, and finance) are likely to affect the NPD recentralization process as well through interacting with R\&D or marketing departments. Also, as I observed dual interdependencies between $R \& D$ and marketing, it is still unknown whether dual interdependencies can happen in other departments. Moreover, to have deeper analysis, this study focuses on two dimensions (power centralization and pluralistic input) only. Future research can explore whether there are more relevant dimensions of NPD recentralization, given that NPD tasks encompass many aspects. For example, performance measurement and project (time) management approaches (Clark and Fujimoto, 1991) may be relevant and can be examined in future studies. Finding more 
relevant dimensions can reveal the complexity of NPD recentralization even further.

\section{References}

Achcaoucaou, F., Miravitlles, P., León-Darder, F., 2014. Knowledge sharing and subsidiary R\&D mandate development: A matter of dual embeddedness. International Business Review 23, 76-90.

Adams, M.E., Day, G.S., Dougherty, D., 1998. Enhancing new product development performance: An organizational learning perspective. Journal of Product Innovation Management 15, 403-422.

Amburgey, T.L., Kelly, D., Barnett, W.P., 1993. Resetting the clock: The dynamics of organizational change. Administrative Science Quarterly 38, 51-73.

Argyres, N.S., Silverman, B.S., 2004. R\&D, organization structure, and the development of corporate technological knowledge. Strategic Management Journal 25, 929-958.

Asakawa, K., 1996. External-internal linkages and overseas autonomy-control tension: The management dilemma of the Japanese R\&D in Europe. IEEE Transactions on Engineering Management 43, 24-32.

Asakawa, K., 2001. Organizational tension in international R\&D management: The case of japanese firms. Research Policy 30, 735-757.

Asakawa, K., Som, A., 2008. Internationalization of R\&D in China and India: Conventional wisdom versus reality. Asia Pacific Journal of Management 25, 375-394.

Awate, S., Larsen, M.M., Mudambi, R., 2015. Accessing vs sourcing knowledge: A comparative study of R\&D internationalization between emerging and advanced economy firms. Journal of International Business Studies 46, 63-86.

Bartlett, C.A., Ghoshal, S., 1988. Organizing for worldwide effectiveness: The transnational solution. California Management Review 31, 54-74.

Bartlett, C.A., Ghoshal, S., 1998. Managing across borders: The transnational solution, 2nd ed. Harvard Business School Press, Boston, Mass.

Bartlett, C.A., Ghoshal, S., 2000. Transnational Management: Text, Cases, and Readings in Cross-border Management, 3rd ed. Irwin McGraw-Hill, Boston.

Belderbos, R., Leten, B., Suzuki, S., 2013. How global is R\&D? Firm-level determinants of home-country bias in R\&D. Journal of International Business Studies 44, 765-786.

Beugelsdijk, S., Jindra, B., 2018. Product innovation and decision-making autonomy in subsidiaries of multinational companies. Journal of World Business 53, 529-539.

Beugelsdijk, S., Nell, P.C., Ambos, B., 2017. When do distance effects become empirically observable? An investigation in the context of headquarters value creation for subsidiaries. Journal of International Management 23, 255-267.

Burgelman, R.A., Maidique, M.A., Wheelwright, S.C., 1996. Strategic management of technology and innovation. Irwin, Chicago.

Castellion, G., Markham, S.K., 2013. Perspective: New product failure rates: Influence of argumentum ad populum and self-interest. Journal of Product Innovation Management 30, 976-979.

Chandy, R., Hopstaken, B., Narasimhan, O., Prabhu, J., 2006. From invention to innovation: Conversion ability in product development. Journal of Marketing Research 43, 494-508. 
Chen, C.-J., Huang, Y.-F., Lin, B.-W., 2012. How firms innovate through R\&D internationalization? An S-curve hypothesis. Research Policy 41, 1544-1554.

Cheng, J.L.C., Bolon, D.S., 1993. The management of multinational R\&D: A neglected topic in international business research. Journal of International Business Studies 24, 1-18.

Chiesa, V., 2000. Global R\&D project management and organization: A taxonomy. Journal of Product Innovation Management 17, 341-359.

Christensen, J.F., 2002. Incongruities as a source of organizational renewal in corporate management of R\&D. Research Policy 31, 1317-1332.

Clark, K.B., Fujimoto, T., 1991. Product Development Performance: Strategy, Organization, and Management in the World Auto Industry. Harvard Business School Press, Boston, Mass.

Cross, R., Cummings, J.N., 2004. Tie and network correlates of individual performance in knowledge-intensive work. Academy of Management Journal 47, 928-937.

De Brentani, U., Kleinschmidt, E.J., Salomo, S., 2010. Success in global new product development: Impact of strategy and the behavioral environment of the firm. Journal of Product Innovation Management 27, 143-160.

Eisenhardt, K.M., 1989. Building theories from case study research. Academy of Management Review 14, 532-550.

Eisenhardt, K.M., Graebner, M.E., 2007. Theory building from cases: Opportunities and challenges. Academy of Management Journal 50, 25-32.

Fotaki, M., Hyde, P., 2015. Organizational blind spots: Splitting, blame and idealization in the national health service. Human Relations 68, 441-462.

Garbe, J.-N., Richter, N.F., 2009. Causal analysis of the internationalization and performance relationship based on neural networks-advocating the transnational structure. Journal of International Management 15, 413-431.

Gassmann, O., von Zedwitz, M., 1999. New concepts and trends in international R\&D organization. Research Policy 28, 231-250.

Geiger, D., Antonacopoulou, E., 2009. Narratives and organizational dynamics: Exploring blind spots and organizational inertia. The Journal of Applied Behavioral Science 45, 411-436.

Granstrand, O., 1999. Internationalization of corporate R\&D: A study of Japanese and Swedish corporations. Research Policy 28, 275-302.

Granstrand, O., Håkanson, L., Sjölander, S., 1993. Internationalization of R\&D—a survey of some recent research. Research Policy 22, 413-430.

Griffin, A., Hauser, J.R., 1993. The voice of the customer. Marketing Science 12, 1-27.

Guellec, D., de la Potterie, B.v.P., 2001. The internationalisation of technology analysed with patent data. Research Policy 30, 1253-1266.

Håkanson, L., 1990. International decentralization of R\&D: The organizational challenges, in: Bartlett, C.A., Doz, Y., Hedlund, G. (Eds.), Managing the Global Firm. Routledge, London.

Harzing, A.-W., 2000. An empirical analysis and extension of the Bartlett and Ghoshal typology of multinational companies. Journal of International Business Studies 31, 101-119.

Hite, J.M., 2005. Evolutionary processes and paths of relationally embedded network ties in emerging entrepreneurial firms. Entrepreneurship Theory and Practice 29, 113-144. 
Hsu, C.-W., Lien, Y.-C., Chen, H., 2015. R\&D internationalization and innovation performance. International Business Review 24, 187-195.

Jarvenpaa, S.L., Leidner, D.E., 1999. Communication and trust in global virtual teams. Organization Science 10, 791-815.

Kim, B., Prescott, J.E., Kim, S.M., 2005. Differentiated governance of foreign subsidiaries in transnational corporations: An agency theory perspective. Journal of International Management 11, 43-66.

Kleinschmidt, E.J., de Brentani, U., Salomo, S., 2007. Performance of global new product development programs: A resource-based view. Journal of Product Innovation Management 24, 419-441.

Lawrence, T.B., Dover, G., 2015. Place and institutional work: Creating housing for the hard-to-house. Administrative Science Quarterly 60, 371-410.

Lehrer, M., Asakawa, K., 2003. Offshore knowledge incubation: The "third path" for embedding R\&D labs in foreign systems of innovation. Journal of World Business 37, 297-306.

Leiponen, A., Helfat, C.E., 2011. Location, decentralization, and knowledge sources for innovation. Organization Science 22, 641-658.

Li, C.R., Yeh, C.H., 2017. Leveraging the benefits of exploratory learning and exploitative learning in NPD: The role of innovation field orientation. R\&D Management 47, 484-497.

Lin, B.-W., Lee, Y., Hung, S.-C., 2006. R\&D intensity and commercialization orientation effects on financial performance. Journal of Business Research 59, 679-685.

Luo, Y., 1999. International strategy and subsidiary performance in China. Thunderbird International Business Review 41, 153-178.

Luo, Y., 2005. Toward coopetition within a multinational enterprise: A perspective from foreign subsidiaries. Journal of World Business 40, 71-90.

McDonough III, E.F., Kahn, K.B., Barczak, G., 2001. An investigation of the use of global, virtual, and colocated new product development teams. Journal of Product Innovation Management 18, 110-120.

Meyer, A., Mizushima, A., 1989. Global R\&D management. R\&D Management 19, 135-146.

Miles, M.B., Huberman, A.M., 1994. Qualitative Data Analysis: An Expanded Sourcebook. Sage, Thousand Oaks, CA.

Moenaert, R.K., Souder, W.E., 1990. An information transfer model for integrating marketing and R\&D personnel in new product development projects. Journal of Product Innovation Management 7, 91-107.

Niosi, J., 1999. The internationalization of industrial R\&D: From technology transfer to the learning organization. Research Policy 28, 107-117.

Nobel, R., Birkinshaw, J., 1998. Innovation in multinational corporations: Control and communication patterns in international R\&D. Strategic Management Journal 19, 479-496.

Patel, P., Vega, M., 1999. Patterns of internationalisation of corporate technology: Location vs. Home country advantages. Research Policy 28, 145-155.

Perlmutter, H.V., 1969. The tortuous evolution of the multinational corporation. Columbia Journal of World Business 4, 9-18.

Reger, G., 2004. Coordinating globally dispersed research centres of excellence-the case of Philips Electronics. Journal of International Management 10, 51-76. 
Rumelt, R.P., 1995. Inertia and transformation, in: Montgomery, C.A. (Ed.), Resource-based and Evolutionary Theories of the Firm: Towards a Synthesis. Springer, Boston, MA, pp. 101-132.

Shu, C., Wang, Q., Gao, S., Liu, C., 2015. Firm patenting, innovations, and government institutional support as a double-edged sword. Journal of Product Innovation Management 32, 290-305.

Subramaniam, M., Rosenthal, S.R., Hatten, K.J., 1998. Global new product development processes: Preliminary findings and research propositions. Journal of Management Studies 35, 773-796.

Subramaniam, M., Venkatraman, N., 2001. Determinants of transnational new product development capability: Testing the influence of transferring and deploying tacit overseas knowledge. Strategic Management Journal 22, 359-378.

Ulrich, K.T., Eppinger, S.D., 2012. Product Design and Development, 5th ed. McGraw-Hill, New York.

Un, C.A., Rodríguez, A., 2018. Local and global knowledge complementarity: R\&D collaborations and innovation of foreign and domestic firms. Journal of International Management 24, 137-152.

Van Beers, C., Berghäll, E., Poot, T., 2008. R\&D internationalization, R\&D collaboration and public knowledge institutions in small economies: Evidence from Finland and the Netherlands. Research Policy 37, 294-308.

Von Nordenflycht, A., 2010. What is a professional service firm? Toward a theory and taxonomy of knowledge-intensive firms. Academy of Management Review 35, 155-174.

von Zedtwitz, M., Gassmann, O., 2002. Market versus technology drive in R\&D internationalization: Four different patterns of managing research and development. Research Policy 31, 569-588.

Von Zedtwitz, M., Gassmann, O., Boutellier, R., 2004. Organizing global R\&D: Challenges and dilemmas. Journal of International Management 10, 21-49.

Wheelwright, S.C., Clark, K.B., 1992. Revolutionizing Product Development: Quantum Leaps in Speed, Efficiency, and Quality. The Free Press, New York.

Wortmann, M., 1990. Multinationals and the internationalization of R\&D: New developments in German companies. Research Policy 19, 175-183.

Yin, R.K., 2009. Case Study Research: Design and Methods, 4th ed. Sage, Los Angeles, CA.

Table 1 Summary of case companies

\begin{tabular}{|c|c|c|c|c|}
\hline Cases & Car Corp & Switch Corp & Cleaning Corp & Fridge Corp \\
\hline Revenue at $2012^{1}$ & $\$ 127$ billion & $\$ 10$ billion & $\$ 12$ billion & \$5 billion \\
\hline $\begin{array}{l}\text { Revenue at the } \\
\text { start/end of NPD } \\
\text { recentralization }\end{array}$ & $\begin{array}{l}\text { \$154 billion/ } \\
\$ 129 \text { billion }{ }^{2}\end{array}$ & $\begin{array}{l}\$ 7 \text { billion/ } \$ 7 \\
\text { billion }\end{array}$ & $\begin{array}{l}\$ 10 \text { billion } / \$ 11 \\
\text { billion }\end{array}$ & $\begin{array}{l}\text { \$4 billion/ \$4 } \\
\text { billion }\end{array}$ \\
\hline Industry & Automotive & Power products & Cleaning products & Home appliance \\
\hline Headquarters location & The U.S. & Switzerland & The U.K. & Sweden \\
\hline NPD recentralization & $2007-2008$ & 2001-2002 & 1998-2011 & 1992-2009 \\
\hline
\end{tabular}




\begin{tabular}{|c|l|l|l|l|}
\hline time period & & & & \\
\hline $\begin{array}{c}\text { Number of interviews } \\
\text { (interviewees) }\end{array}$ & $12(9)$ & $14(12)$ & $15(12)$ & $16(11)$ \\
\hline Company Informants & Executive & Executive & Executive & Executive \\
& Product director & Global product & Product director \\
& R\&D manager & R\&D manager & manager \\
& Engineer & R\&D manager & Scientist & R\&D manager \\
& Product designer & Engineer & Marketing & Engineer \\
& Marketing & Marketing & manager & Marketing \\
& manager & manager & & managr \\
\hline
\end{tabular}

${ }^{1}$ Revenues are converted to U.S. dollar by yearly average exchange rates.

${ }^{2}$ Decrease due to divestment. 
Table 2 Representative quotes for NPD recentralization

\begin{tabular}{|c|c|}
\hline Company & Representative Quotes \\
\hline & 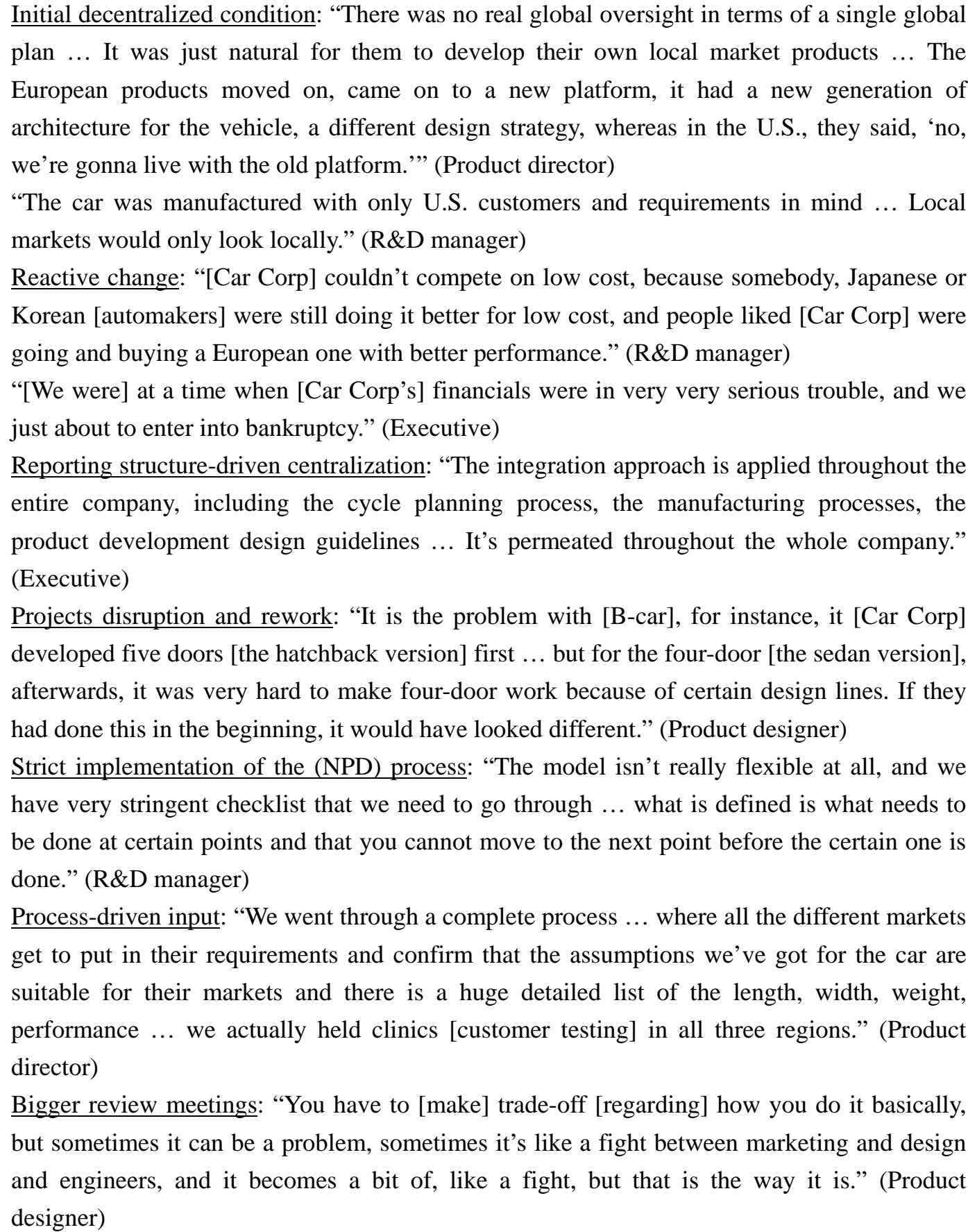 \\
\hline $\begin{array}{l}\text { Switch } \\
\text { Corp }\end{array}$ & $\begin{array}{l}\text { Initial decentralized condition: "At that time, [Switch Corp] had a lot of factories and each } \\
\text { factory developed and produced different types of circuit breakers and also switchgears." } \\
\text { (R\&D manager) } \\
\text { "[The NPD team] can meet with two, three people here [locally] in the company and decide } \\
\text { what should be developed and what the requirements are and so on." (R\&D manager) } \\
\text { Reactive change: "Little or no global coordination ... huge overlapping in product portfolio } \\
\text { and producing units ... R\&D and portfolio maintenance costs rocketing." (Internal document) } \\
\text { Reporting structure-driven centralization: "We have a project manager who is really }\end{array}$ \\
\hline
\end{tabular}




\begin{tabular}{|c|c|}
\hline & $\begin{array}{l}\text { responsible for the entire project [globally], and then we have [local] work package } \\
\text { managers ... and they will be reporting to the project manager in a different country." (R\&D } \\
\text { manager) } \\
\text { Projects disruption and rework: "These requirements [from other countries] were not } \\
\text { considered initially because the product was targeted at one country, so a lot of changes were } \\
\text { made later on.” (R\&D manager) } \\
\text { Flexible implementation of the (NPD) process: "We wouldn't do Gate } 0 \text { and 1, we would } \\
\text { jump directly to Gate 2, and even then, sometimes Gate } 3 \text {, } 4 \text { and } 5 \text { would be thrown } \\
\text { together ... The department likes to twist it to fit in with the way they like to do things." } \\
\text { (R\&D manager) } \\
\text { Delegate-driven input: "We have the global product manager ... these people will study the } \\
\text { different markets.” (Executive) } \\
\text { "There is a local product manager in each country, with some exceptions, and there is also } \\
\text { global product manager, and they all have to compile the requirements and compile the } \\
\text { Market Requirement Specification, which is the document saying what they are, what they } \\
\text { need, what they want. And we transfer this market requirement specification into a more } \\
\text { technical document, which is Technological Requirement Specification, which says more in } \\
\text { detail what we are going to develop.” (R\&D manager) } \\
\text { Frequent interaction: "We kept [in] close contact with the global product manager, sometimes } \\
\text { we held meetings to discuss the project formally, sometimes I just call or email him to ask } \\
\text { quick questions.” (R\&D manager) }\end{array}$ \\
\hline & $\begin{array}{l}\text { Initial decentralized condition: “At that time, most of the major [Cleaning Corp] operating } \\
\text { companies had their own R\&D departments ... capable of more or less doing any product } \\
\text { development." (Executive) } \\
\text { "Local product development created them [products] often for the local factory, they could be } \\
\text { very different between adjacent countries.” (Executive) } \\
\text { Proactive change: "Any activities were locally based ... at the moment, the big group was } \\
\text { realizing that working as before was wrong.” (R\&D manager) } \\
\text { "So if you don't go for regional sourcing ... and don't do standardization of products where it } \\
\text { makes sense, you just lose completely on the economies of scale.” (Executive) } \\
\text { Capacity-driven centralization: "The first stage of the process was to migrate from country } \\
\text { structures into regional structures. Once the strategic direction has been set, this was } \\
\text { implemented through shifting budgets and resources from countries to regions. This didn't } \\
\text { mean the country R\&D structures were wiped out; rather it meant they now didn't have the } \\
\text { resources available to develop their own activities and had to work with their regional } \\
\text { counterparts.” (R\&D manager) } \\
\text { Gradual projects replacement: "It did not change overnight ... it was more and more } \\
\text { regionally led, but local teams still took care of local projects.” (R\&D manager) } \\
\text { Strict implementation of the (NPD) process: “To be honest, most of the process stuff was for } \\
\text { managers who could not discuss ideas, so they hide behind process-speak which bored the } \\
\text { pants off anyone doing anything useful.” (Scientist) } \\
\text { Process-driven input: “At the start of each NPD process the input from all the countries where } \\
\text { the product is to be launched is taken and studied by the project team.” (R\&D manager) } \\
\text { Bigger review meetings: "Every checkpoint they would, during project, [local] marketing }\end{array}$ \\
\hline
\end{tabular}




\begin{tabular}{|c|c|}
\hline & $\begin{array}{l}\text { would be there in the meeting, they cannot miss it, you cannot hold the checkpoint meeting } \\
\text { without the local marketing boys ... more people to keep satisfied, than it used to be, when it } \\
\text { was only local thing ... it goes back and forward, back and forward, sometimes can be very } \\
\text { heated discussion, and then at the end we agree, what will do.” (R\&D manager) }\end{array}$ \\
\hline $\begin{array}{l}\text { Fridge } \\
\text { Corp }\end{array}$ & $\begin{array}{l}\text { Initial decentralized condition: "So each of the factories had its own R\&D ... local R\&D in } \\
\text { different factories, Spain, Sweden, etc.” (Product line manager) } \\
\text { "Italy was thinking only about Italian requirements ... if the product was also good for } \\
\text { another market, also it would be sold on another market.” (Engineer) } \\
\text { Proactive change: "To have five R\&D is not efficient, so it's better one.” (R\&D manager) } \\
\text { "Being a major company competing on the global market, we had to take the benefits of the } \\
\text { size, and then you have to bring R\&D together." (Executive) } \\
\text { Capacity-driven centralization: "We increased our staff [here], and then slowly reduced } \\
\text { people there ... They take our project and put on the door with this color.” (R\&D manager) } \\
\text { Gradual projects replacement: "We had more and more big projects over time for everyone. } \\
\text { The local centers, they developed less and less, due to lack of resources to initiate projects." } \\
\text { (R\&D manager) } \\
\text { Flexible implementation of the (NPD) process: "The process is there with specific tasks } \\
\text { defined, but what tasks will actually be done is at our own discretion so as to complete the } \\
\text { project in an efficient manner.” (Engineer) } \\
\text { Delegate-driven input: "I was organizing the feedback from the different regions [sub-regions } \\
\text { in Europe like Southern Europe], so the local [country] spoke to the region, and the region } \\
\text { spoke to Europe, to the central organization, so feedback was organized from the bottom to } \\
\text { the top.” (Product line manager) } \\
\text { Frequent interaction: "We worked closely with the product line manager, who provided } \\
\text { information throughout the product development projects ... his role is very important to us.” } \\
\text { (Engineer) }\end{array}$ \\
\hline
\end{tabular}




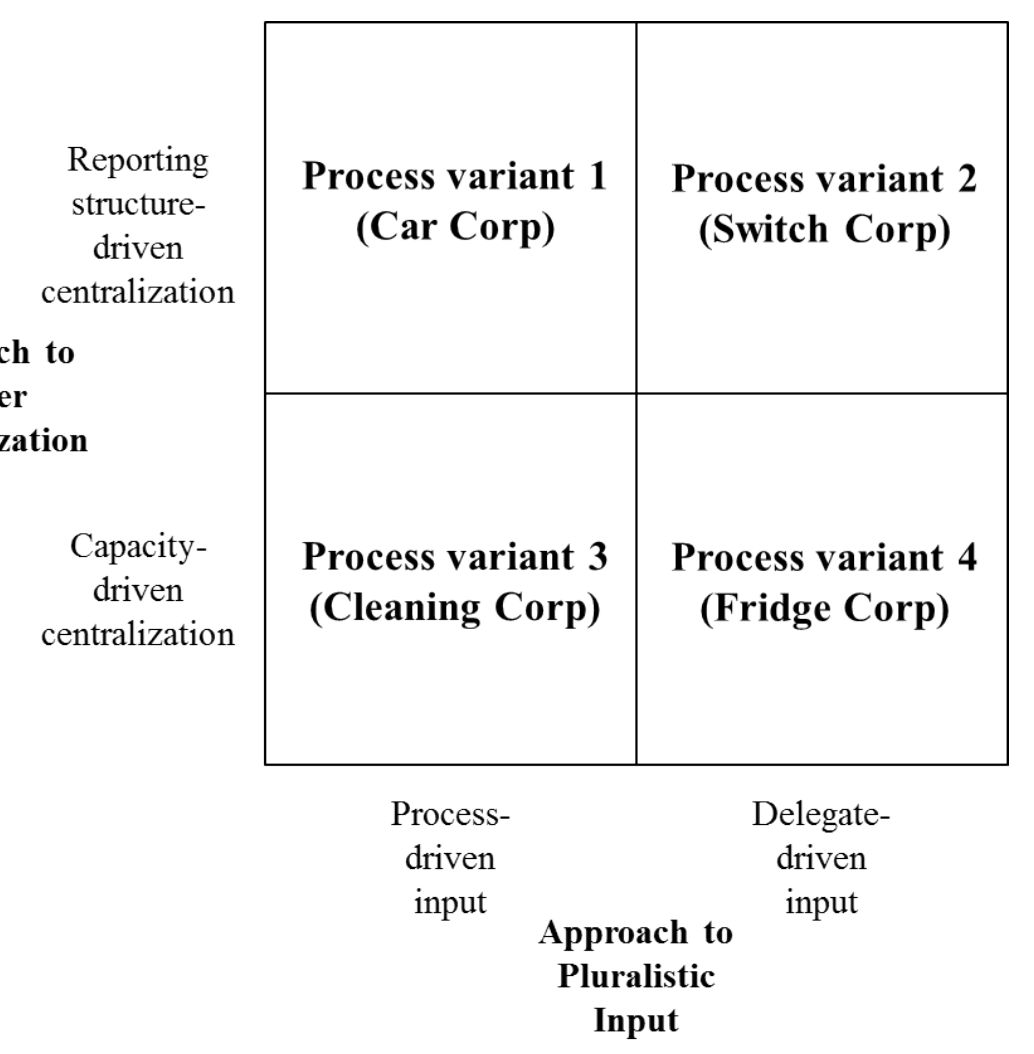

Figure 1 Four process variants of NPD recentralization
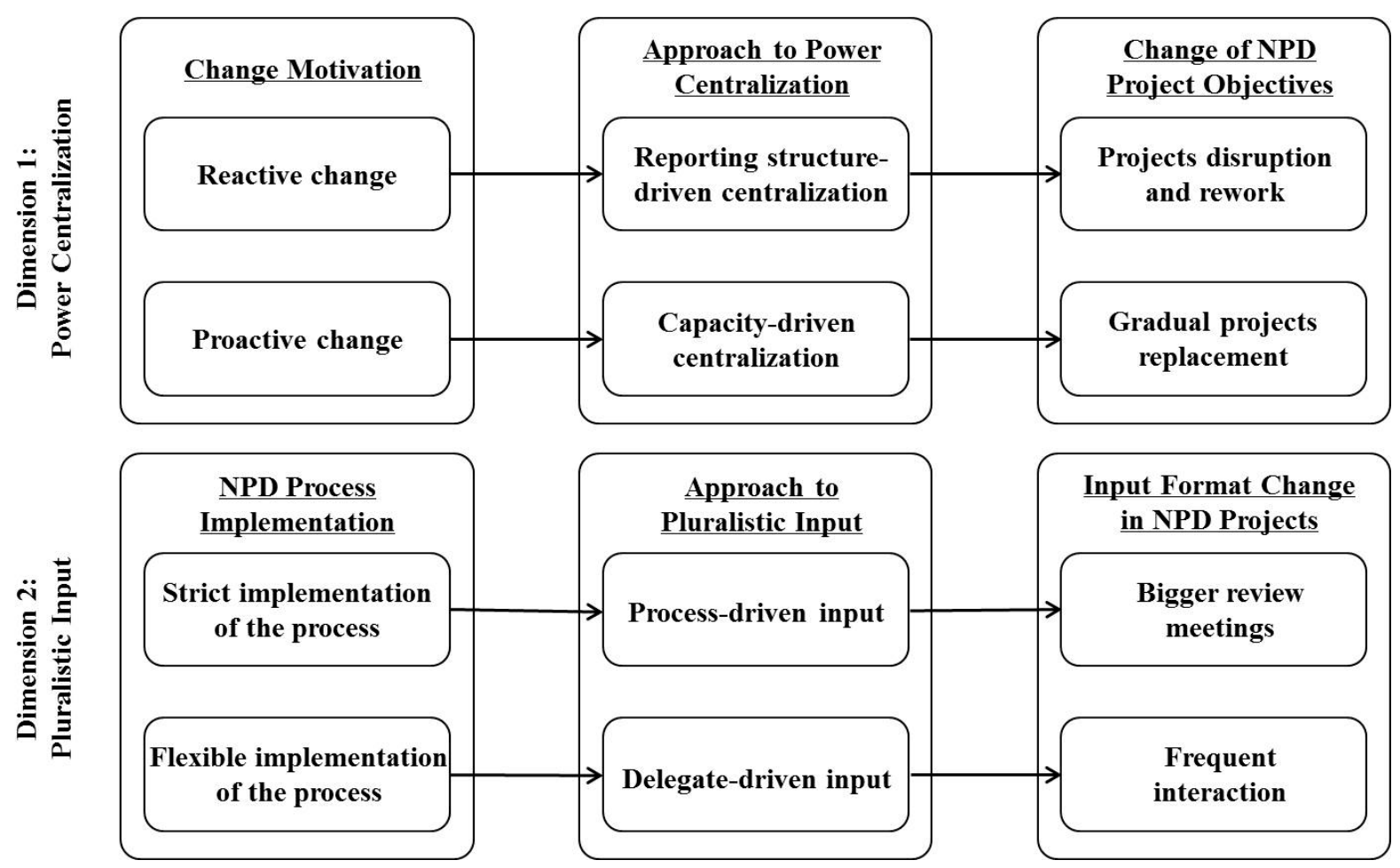

Figure 2 A two-dimensional process of NPD recentralization 


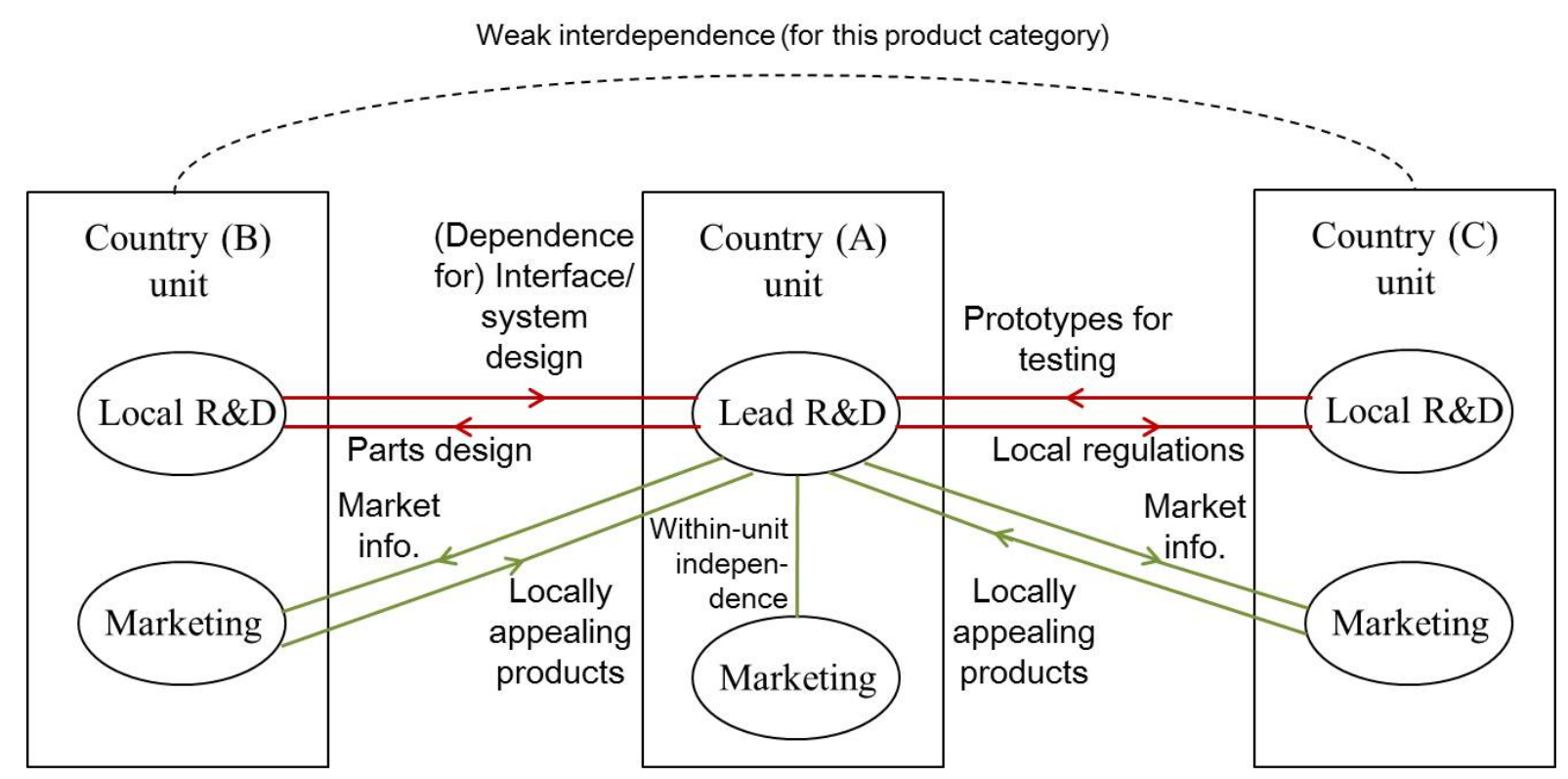

$\longrightarrow$ Dependence for technological excellence

Dependence for market fulfillment

Figure 3 Dual interdependencies across country units (for a product category)

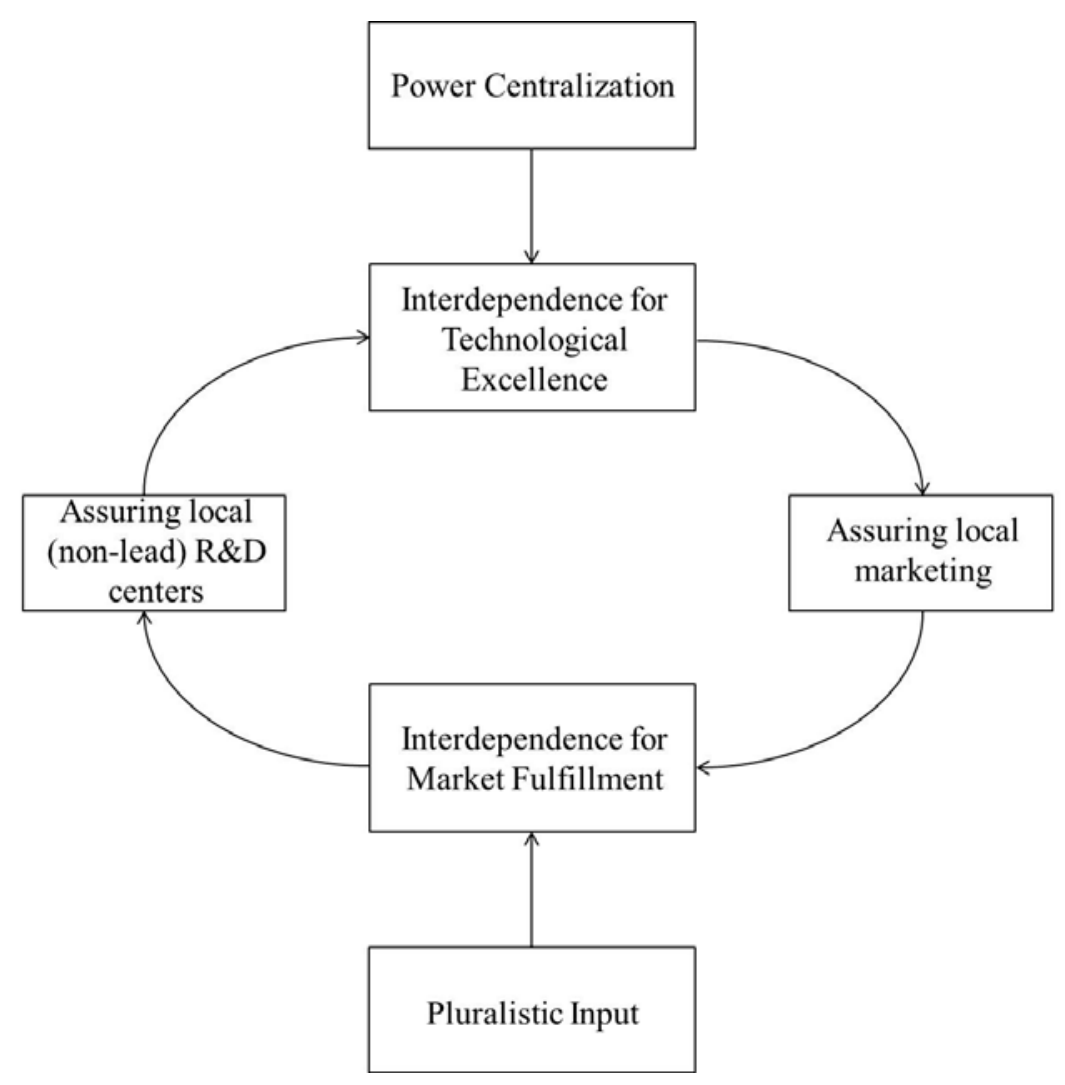

Figure 4 The reinforcing mechanism of dual interdependencies 